\title{
Review
}

Drug/Regimen

Diabetes Metab J 2020;44:213-221

https://doi.org/10.4093/dmj.2020.0001

pISSN 2233-6079 · eISSN 2233-6087

DIABET\&S \& METABOLISM JOURNAL

\section{Fibrates Revisited: Potential Role in Cardiovascular Risk Reduction}

\author{
Nam Hoon Kim, Sin Gon Kim \\ Department of Internal Medicine, Korea University College of Medicine, Seoul, Korea
}

Fibrates, peroxisome proliferator-activated receptor- $\alpha$ agonists, are potent lipid-modifying drugs. Their main effects are reduction of triglycerides and increase in high-density lipoprotein levels. Several randomized controlled trials have not demonstrated their benefits on cardiovascular risk reduction, especially as an "add on" to statin therapy. However, subsequent analyses by major clinical trials, meta-analyses, and real-world evidence have proposed their potential in specific patient populations with atherogenic dyslipidemia and metabolic syndrome. Here, we have reviewed and discussed the accumulated data on fibrates to understand their current status in cardiovascular risk management.

Keywords: Cardiovascular diseases; Dyslipidemias; Hydroxymethylglutaryl-CoA reductase inhibitors; Metabolic syndrome; Peroxisome proliferator-activated receptors; PPAR alpha

\section{INTRODUCTION}

Dyslipidemia, which was previously considered to only affect patients with genetic susceptibility, has now become one of the most prevalent chronic metabolic disorders. The prevalence of dyslipidemia in Korea has reached $40 \%$ in adults over 20 years of age [1]; consequently, the use of lipid-modifying drugs has increased rapidly [2]. The role of low-density lipoprotein cholesterol (LDL-C) in the formation of atherosclerosis, development of therapeutic agents acting on the LDL receptor, and success of large clinical trials of 3-hydroxy-3-methylglutaryl coenzyme A reductase inhibitors (statins) has significantly affected the current paradigm of "lowering LDL-C levels using statins" for reduction of cardiovascular risk [3-5]. Although this is still "the era of statins," recent clinical and epidemiological studies have noted the residual risk of cardiovascular disease (CVD) that statins do not manage, and some studies have demonstrated the potential role of non-statin drugs in the management of residual cardiovascular risk [6,7]. Fibrates are lipid-modifying drugs that act mainly to elevate triglycerides (TG) and lower the levels of high-density lipoprotein cholesterol (HDL-C). Early clinical trials of fibrates were promising, but their role in cardiovascular risk management has gradually diminished in the statin era. The major guidelines also limited the use of fibrates to adults with severe hypertriglyceridemia (fasting TG $\geq 500 \mathrm{mg} / \mathrm{dL}$ ) or those at high cardiovascular risk with hypertriglyceridemia only in combination with statins $[8,9]$.

However, recent studies have demonstrated that fibrate drugs, particularly fenofibrate, have a therapeutic role in dyslipidemia, especially in patients with metabolic syndrome traits. Here, we have reviewed recent data on fibrates and discussed the appropriate use of fibrates in clinical practice.

\section{PHARMACOLOGIC ACTION OF FIBRATES}

Fibrates have been used as clinical treatments since the 1960s; however, it was not until the early 1990s that their mechanism

\footnotetext{
Corresponding author: Sin Gon Kim (D) https://orcid.org/0000-0002-7430-3675 Division of Endocrinology and Metabolism, Department of Internal Medicine, Korea University Anam Hospital, Korea University College of Medicine, 73 Goryeodae-ro, Seongbuk-gu, Seoul 02841, Korea

E-mail: k50367@korea.ac.kr

This is an Open Access article distributed under the terms of the Creative Commons Attribution Non-Commercial License (https://creativecommons.org/licenses/by-nc/4.0/) which permits unrestricted non-commercial use, distribution, and reproduction in any medium, provided the original work is properly cited. 
of action was identified. Fibrates have multiple pharmacological actions, mainly as a synthetic ligand for the peroxisome proliferator-activated receptors (PPARs), especially PPAR $\alpha$. PPARs belong to a family of nuclear receptors known to regulate carbohydrate and lipid metabolism and adipocyte differentiation [10]. When a ligand binds to PPAR, it induces conformational changes that allow the recruitment of coactivators. Subsequently, PPAR forms a heterodimer with another nuclear receptor, the retinoid X receptor (RXR) [11]. The complex recognizes and binds to PPAR response elements (PPREs) in the promoter region of the target genes and regulates the expression of various genes. The lipid-modifying activity of fibrate occurs mainly through PPAR $\alpha$ activation. Clinically, fibrates reduce plasma TG or TG-rich lipoproteins (TRLs) and increase HDL concentration through various PPAR $\alpha$ actions, including: (1) increased lipolysis via lipoprotein lipase (LPL) activation and ApoC-III suppression [12,13]; (2) increased hepatic fatty acid uptake through fatty acid transporter protein (FATP) and acyl-coA synthetase induction [14,15]; and (3) increased ApoA-I and ApoA-II synthesis [16]. In addition, fibrates were found to have anti-atherogenic effects through reduction in vascular cell adhesion molecule (VCAM) and monocyte chemoattractant protein-1 (MCP-1) [17], and antiinflammatory effects were identified to occur through the reduction of the expression of various proinflammatory genes and inflammatory markers [18].

\section{RESIDUAL RISK OF CARDIOVASCULAR DISEASE AND THE ROLE OF ATHEROGENIC DYSLIPIDEMIA}

Currently, the major guidelines for dyslipidemia management recommend statin treatment for most cardiovascular risk groups $[2,8,9]$. The LDL-C target differs by guideline, but it is conventionally recommended to stay below $100 \mathrm{mg} / \mathrm{dL}$ in the high risk group and below $70 \mathrm{mg} / \mathrm{dL}$ in the very high risk group of CVD. One of the unresolved issues is the continued significant risk of CVD despite adequate statin treatments $[6,19]$. Therefore, the methods of measuring and managing this residual cardiovascular risk remains an important issue. There is considerable evidence from the post hoc analyses of major randomized controlled trials (RCTs) of statins or meta-analyses for the assessment and prediction of residual cardiovascular risk. Although there is no consensus yet, lipid or lipoprotein parameters, such as non-HDL-C [20], TG [21], HDL-C [22], small very low-density lipoprotein (VLDL) particles [23], and the ApoB/A-I ratio [24], have been verified as the predictors. Among these, a number of studies have focused on the traits of atherogenic dyslipidemia (elevated TG, and small dense LDL particles with a low level of HDL-C), which are components of metabolic syndrome and are directly related to insulin resistance [25]. Both on-treatment HDL-C level in the post hoc analysis of the Treating to New Targets (TNT) trial [22] and on-treatment TG level in the Pravastatin or Atorvastatin Evaluation and Infection Trial (PROVE IT) trial [21] were identified as independent predictors of the residual risk of CVD. In addition, similar results were obtained from the Prevention of Cerebrovascular and Cardiovascular Events of Ischemic Origin With Terutroban in Patients With a History of Ischemic Stroke or Transient Ischemic Attack (PERFORM) and the Stroke Prevention by Aggressive Reduction in Cholesterol Levels (SPARCL) studies [26] and a meta-analysis study [27]. In the statin era, atherogenic dyslipidemia is not just a phenotype of metabolic syndrome or insulin resistance, but also a predictor of future CVD and a medical state to be managed.

Therefore, research into the clinical effects of drugs that directly affect TG and HDL-C, including niacin, fibrates, n-3 fatty acids, and cholesteryl ester transfer protein (CETP) inhibitors, has continued. In the early 2010s, the use of these nonstatin drugs was viewed skeptically, based on large-scale RCTs that showed no reduction in major cardiovascular events when added to statins [28-33]. However, more recent evidence has identified results that may combat this skepticism; these are described elsewhere $[7,34]$. In this review, we have focused on the details of fibrate research.

\section{CLINICAL TRIALS OF FIBRATES}

The history of cardiovascular outcome trials (CVOTs) of fibrate drugs dates back to 1987 (Table 1). The Helsinki Heart Study (HHS) evaluated the effects of gemfibrozil on major CVD in 4,081 patients with dyslipidemia 7 years earlier than the Scandinavian Simvastatin Survival Study (4S), which was the first CVOT of statins [35]. The HHS included asymptomatic middle-aged men with primary dyslipidemia (non-HDL$\mathrm{C} \geq 200 \mathrm{mg} / \mathrm{dL}$ ) without CVD. The primary endpoint was fatal and nonfatal myocardial infarction (MI) and cardiac death. The results showed that gemfibrozil significantly reduced the primary endpoints by $34 \%$ compared with placebo. Subsequently, the Veterans Affairs HDL Intervention Trial (VA-HIT) 
Table 1. Major clinical trials and epidemiological studies of fibrates

\begin{tabular}{|c|c|c|c|c|c|c|c|c|}
\hline & $\begin{array}{l}\text { Study } \\
\text { type }\end{array}$ & Population & No. & Study drug & Comparator & $\begin{array}{l}\text { Primary } \\
\text { outcome }\end{array}$ & Results & $\begin{array}{l}\text { Additional } \\
\text { findings }\end{array}$ \\
\hline HHS (1987) & RCT & Dyslipidemia & 4,081 & $\begin{array}{l}\text { Gemfibrozil } \\
1,200 \text { mg/day }\end{array}$ & Placebo & $\begin{array}{l}\text { Fatal and } \\
\text { non-fatal MI or } \\
\text { cardiac death }\end{array}$ & $34 \%{ }^{\mathrm{a}}$ reduction & \\
\hline VA-HIT (1999) & RCT & CHD & 2,531 & $\begin{array}{l}\text { Gemfibrozil } \\
1,200 \mathrm{mg} / \text { day }\end{array}$ & Placebo & $\begin{array}{l}\text { Non-fatal MI or } \\
\text { coronary death }\end{array}$ & $22 \%{ }^{\mathrm{a}}$ reduction & \\
\hline $\mathrm{BIP}(2000)$ & RCT & $\mathrm{CHD}$ & 3,090 & $\begin{array}{l}\text { Bezafibrate } \\
400 \mathrm{mg} / \text { day }\end{array}$ & Placebo & $\begin{array}{l}\text { Fatal or nonfatal } \\
\text { MI or sudden } \\
\text { death }\end{array}$ & $\begin{array}{l}9.4 \% \text { reduction } \\
(\mathrm{NS})\end{array}$ & $\begin{array}{l}41.8 \% \text { reduction in } \\
\text { subgroup (HDL-C } \\
<35 \mathrm{mg} / \mathrm{dL}, \mathrm{TG} \\
\geq 200 \mathrm{mg} / \mathrm{dL})\end{array}$ \\
\hline LEADER (2002) & RCT & Lower PAD & 1,568 & $\begin{array}{l}\text { Bezafibrate } \\
400 \mathrm{mg} / \text { day }\end{array}$ & Placebo & CHD or stroke & $4 \%$ reduction (NS) & $\begin{array}{c}40 \% \text { reduction of } \\
\text { non-fatal CHD }\end{array}$ \\
\hline FIELD (2005) & RCT & $\mathrm{T} 2 \mathrm{DM}$ & 9,795 & $\begin{array}{l}\text { Fenofibrate } \\
200 \mathrm{mg} / \text { day }\end{array}$ & Placebo & $\begin{array}{l}\text { CHD death or } \\
\text { non-fatal MI }\end{array}$ & $\begin{array}{l}11 \% \text { reduction } \\
\text { (NS) }\end{array}$ & $\begin{array}{c}24 \% \text { reduction of } \\
\text { non-fatal MI }\end{array}$ \\
\hline $\begin{array}{l}\text { ACCORD-Lipid } \\
\text { (2010) }\end{array}$ & RCT & $\mathrm{T} 2 \mathrm{DM}$ & 5,518 & $\begin{array}{l}\text { Simvastatin plus } \\
\text { fenofibrate } \\
160 \mathrm{mg} / \text { day }\end{array}$ & Simvastatin & $\begin{array}{l}\text { Non-fatal MI, } \\
\text { non-fatal stroke, } \\
\text { cardiovascular } \\
\text { death }\end{array}$ & $8 \%$ reduction (NS) & $\begin{array}{l}\text { 28.6\% reduction in } \\
\text { subgroup (HDL-C } \\
\leq 34 \mathrm{mg} / \mathrm{dL}, \mathrm{TG} \\
\geq 204 \mathrm{mg} / \mathrm{dL})\end{array}$ \\
\hline $\begin{array}{l}\text { ACCORDION } \\
(2017)\end{array}$ & $\begin{array}{l}\text { Post- } \\
\text { trial } \\
\mathrm{f} / \mathrm{u}\end{array}$ & $\mathrm{T} 2 \mathrm{DM}$ & 4,644 & $\begin{array}{l}\text { Simvastatin plus } \\
\text { fenofibrate } \\
160 \mathrm{mg} / \text { day }\end{array}$ & Simvastatin & $\begin{array}{l}\text { Non-fatal MI, } \\
\text { non-fatal stroke, } \\
\text { cardiovascular } \\
\text { death }\end{array}$ & $7 \%$ reduction $(\mathrm{NS})$ & $\begin{array}{l}\text { 27\% reduction in } \\
\text { subgroup (HDL-C } \\
\leq 34 \mathrm{mg} / \mathrm{dL}, \mathrm{TG} \\
\geq 204 \mathrm{mg} / \mathrm{dL})\end{array}$ \\
\hline $\begin{array}{l}\text { Three City Study } \\
\text { (2015) }\end{array}$ & Cohort & $\begin{array}{l}\text { Elderly with- } \\
\text { out CVD }\end{array}$ & 7,484 & $\begin{array}{l}\text { Statins or fi- } \\
\text { brates }\end{array}$ & $\begin{array}{l}\text { No lipid } \\
\text { lowering } \\
\text { drugs }\end{array}$ & CHD or stroke & $\begin{array}{l}\text { Fibrates: } 34 \%^{\mathrm{a}} \\
\text { reduction of } \\
\text { stroke, } 12 \% \\
\text { increase in CHD } \\
\text { (NS) }\end{array}$ & \\
\hline $\begin{array}{l}\text { ECLIPSE-REAL } \\
\text { (2019) }\end{array}$ & Cohort & $\begin{array}{l}\text { Metabolic } \\
\text { syndrome }\end{array}$ & 10,705 & $\begin{array}{l}\text { Statin plus } \\
\text { fenofibrate } \\
160 \mathrm{mg} / \text { day }\end{array}$ & $\begin{array}{l}\text { Statin } \\
\text { monotherapy }\end{array}$ & $\begin{array}{l}\text { CHD, stroke, } \\
\text { cardiovascular } \\
\text { death }\end{array}$ & $26 \%{ }^{\mathrm{a}}$ reduction & $\begin{array}{l}36 \% \text { reduction in } \\
\text { subgroup (HDL-C } \\
<34 \mathrm{mg} / \mathrm{dL}, \mathrm{TG} \\
\geq 204 \mathrm{mg} / \mathrm{dL})\end{array}$ \\
\hline
\end{tabular}

HHS, Helsinki Heart Study; RCT, randomized controlled trial; MI, myocardial infarction; VA-HIT, Veterans Affairs HDL Intervention Trial; CHD, coronary heart disease; BIP, Bezafibrate Infarction Prevention; NS, non-significant; HDL-C, high-density lipoprotein cholesterol; TG, triglyceride; LEADER, Lower Extremity Arterial Disease Event Reduction; PAD, peripheral artery disease; FIELD, Fenofibrate Intervention and Event Lowering in Diabetes; T2DM, type 2 diabetes mellitus; ACCORD, Action to Control Cardiovascular Risk in Diabetes; ACCORDION, ACCORD Follow-On; f/u, follow-up; CVD, cardiovascular disease; ECLIPSE-REAL, Effectiveness of Fenofibrate Therapy in Residual Cardiovascular Risk Reduction in the Real World Setting.

${ }^{a}$ Statistically significant.

study, a secondary prevention trial, confirmed the benefit of gemfibrozil on cardiovascular risk reduction in patients with coronary heart disease (CHD), either [36]. However, the two outcome trials of bezafibrate, the Bezafibrate Infarction Prevention (BIP) study and the Lower Extremity Arterial Disease Event Reduction (LEADER) study, failed to demonstrate cardiovascular risk reduction compared with placebo $[37,38]$. The characteristics of participants in the two bezafibrate studies were similar to those of the VA-HIT trial as secondary preven- tion trials. Thus, a few possible explanations were suggested for the different results between gemfibrozil and bezafibrate studies. Higher rate of use of open-label lipid modification drugs in the placebo group than bezafibrate group was noted explaining the negative results of the BIP and LEADER trials. In part, the lower TG lowering efficacy of bezafibrate than gemfibrozil ( $21 \%$ reduction in the BIP, $23.3 \%$ in the LEADER, and $31 \%$ in the VA-HIT) was also indicated. On the other hand, in the subgroups of patients with high blood TG and low HDL-C levels 
in the BIP study, a significant $41.8 \%$ reduction was identified in the primary outcome, suggesting that the drug could have a beneficial effect in patients with atherogenic dyslipidemia.

In 2005, the Fenofibrate Intervention and Event Lowering in Diabetes (FIELD) study, the first CVOT of fenofibrate as well as the first fibrates study exclusively for type 2 diabetes mellitus patients, was published [39]. Nine thousand seven hundred ninety-five patients with type 2 diabetes mellitus not taking statins at study entry were included. The primary endpoint was CHD death or non-fatal MI. As a result, this study did not show the cardiovascular benefits of fenofibrate compared with placebo; a non-significant $11 \%$ reduction in the primary endpoint (hazard ratio [HR], 0.89; 95\% confidence interval [CI], 0.75 to $1.05 ; P=0.16$ ). At the end of the study, it was suggested that the effects of the study drug may have been masked by almost double the use of lipid-lowering agents other than fenofibrate in the placebo group (36\% vs. 19\%). Smaller reduction of HDL-C than expected and increase in plasma homocysteine concentration with fenofibrate therapy were also suggested as possible reason for the non-significant results although they only explained in part. The subsequent fenofibrate CVOT, the Action to Control Cardiovascular Risk in Diabetes (ACCORD)Lipid trial, aimed to demonstrate the additional benefits of fenofibrate add-on to statins in patients with type 2 diabetes mellitus [33]. Finally, there was no significant difference in the primary outcome between groups, but like as in the BIP study, a substantial risk reduction by $28.6 \%$ was observed in the subgroup of patients with low HDL-C ( $\leq 34 \mathrm{mg} / \mathrm{dL})$ and high TG ( $\geq 204 \mathrm{mg} / \mathrm{dL}$ ). In 2017, a post-trial observation of the ACCORDLipid trial, the ACCORD Follow-On (ACCORDION) study, was published [40]. During a follow-up period of 9.7 years, the main results were not different from the primary ACCORDLipid results. Interestingly, although only $4.3 \%$ of patients continued to take fenofibrate after the end of the original ACCORD-Lipid study, the cardiovascular benefits in the original fenofibrate group with atherogenic dyslipidemia were maintained. Several meta-analyses of fibrate drugs or fenofibrate also have proven that fibrates reduce the cardiovascular risk in patients with atherogenic dyslipidemia or metabolic syndrome [41-43].

Collectively, RCT-based evidence of fibrates in terms of cardiovascular risk reduction seemed not to be consistent. It is still unclear that each individual drugs in fibrate class are different in nature and efficacy. Nevertheless, previous findings in together suggested that fibrates have a possible beneficial role in cardiovascular risk reduction in specific population, especially in patients with an atherogenic dyslipidemia pattern that is closely associated with metabolic syndrome and insulin resistance. As a result, the use of fibrates in those populations, including patients with type 2 diabetes mellitus and atherogenic dyslipidemia, is recommended in many, but not all, guidelines $[2,44,45]$.

\section{REAL WORLD EVIDENCE OF FIBRATES}

In recent years, real-world evidence (RWE) analysis has been actively conducted, along with large-scale population-based cohort construction. The research value of RWE begins at the limits of RCTs. RCTs provide the highest level of evidence in medical science, but the inevitable limitations of RCTs include limited patient population and the trial environment, which is hard to reproduce in the real world. Thus, it is still unclear whether results seen in RCTs can be reproduced in real-world clinical practice. Nowadays, the level of evidence A includes one or more RCTs corroborated by high-quality registry studies [17], recognizing the value of RWE.

The first RWE of fenofibrate, the Three-City Study, was published in 2015 [46]. This was a prospective cohort study of 7,484 elderly patients that compared major cardiovascular outcomes (CHD and stroke) in patients treated with fibrates, statins, and non-lipid-lowering therapy. Both the statin and fibrate groups showed a reduction of approximately $30 \%$ in stroke risk compared with the control group. Recently, we conducted a propensity score (PS)-weighted cohort study, the Effectiveness of Fenofibrate Therapy in Residual Cardiovascular Risk Reduction in the Real World Setting (ECLIPSE-REAL) study, on this issue [47]. This study was designed based on the ACCORD-Lipid trial, but adapted to consider the lessons from this failed trial to prove additional benefits of fenofibrate add-on to statins. From the original cohort of the Korean National Health Insurance Service-Health Screening Cohort (NHIS-HEALS), adults with metabolic syndrome who were the most appropriate candidate for fenofibrate therapy were selected. Subsequently, PS matching was performed for those who were treated with fenofibrate (combined statin plus fenofibrate group) and those who were not (statin monotherapy group). The primary outcome was the major adverse cardiovascular events (MACE) including CHD, ischemic stroke, and cardiovascular death. The primary outcome results by different PS matching population is shown in Fig. 1. In the first matching cohort, based on LDL-C, HDL-C, 


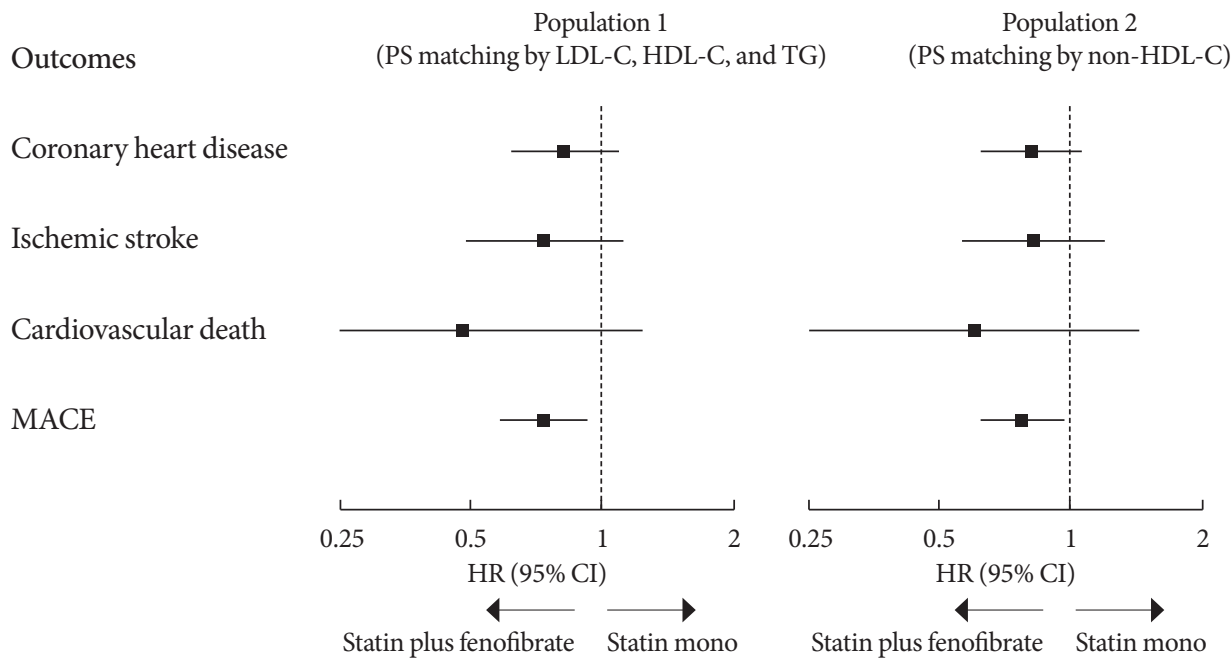

Fig. 1. Summary of primary outcomes in the Effectiveness of Fenofibrate Therapy in Residual Cardiovascular Risk Reduction in the Real World Setting (ECLIPSE-REAL) study. PS, propensity score; LDL-C, low density lipoprotein cholesterol; HDL-C, highdensity lipoprotein cholesterol; TG, triglyceride; MACE, major adverse cardiovascular events; HR, hazard ratio; CI, confidence interval.

and TG levels, the primary outcome was significantly reduced by $26 \%$ in the fenofibrate group (HR, $0.74 ; 95 \% \mathrm{CI}, 0.58$ to 0.93). To better capture the TG-lowering effect on TRLs, a sensitivity analysis was performed on the second cohort matched based on non-HDL-C levels. The results were almost same as those of primary cohort (HR, $0.77 ; 95 \%$ CI, 0.62 to 0.96 for $\mathrm{MACE}$ ). In the atherogenic dyslipidemia subgroup, as defined by the ACCORD-Lipid trial, the risk of MACE was reduced by $36 \%$ with fenofibrate treatment.

The ECLIPSE-REAL study was carefully conducted to exclude important biases such as immortal and time lag biases, recently issued by observational studies [48], nonetheless, a definitive trial of fibrate therapy is still needed for a clearer conclusion. Currently, the Pemafibrate to Reduce Cardiovascular Outcomes by Reducing Triglycerides in Patients with Diabetes (PROMINENT) study, the CVOT of the selective PPAR $\alpha$ modulator pemafibrate, is in progress [49]. This study included patients with type 2 diabetes mellitus with a TG level of $200 \mathrm{mg} / \mathrm{dL}$ or more, and an HDL-C level of $40 \mathrm{mg} / \mathrm{dL}$ or less. It is expected that the results will provide strong evidence for the efficacy of fibrate drugs, considering that the population comprised the optimal candidates for fibrate therapy.

\section{FIBRATES IN METABOLIC SYNDROME}

How can the beneficial effects of fibrates be explained in pa- tients with metabolic syndrome, especially with atherogenic dyslipidemia? First, the lipid modification activity of fenofibrate is dependent on the baseline TG level. Higher baseline TG levels lead to a greater TG lowering efficacy of fenofibrate [50,51]. Even the elevation of HDL-C level by fenofibrate was prominent in patients with hypertriglyceridemia [52]. Therefore, patients with metabolic syndrome and altered lipid metabolism may respond well to fibrate therapy. Second, the complementary and synergistic effect of statins and fenofibrate could be partly attributed to the cardiovascular benefit of fibrates in metabolic syndrome. In a kinetics study, atorvastatin and fenofibrate were found to influence lipoprotein particles and apolipoprotein flux in a complementary manner; the increase in ApoA-I flux and levels due to fenofibrate and the increase in the catabolic rate of ApoB due to atorvastatin both contribute to anti-atherogenic effects [53]. This has been confirmed in clinical studies. Combination therapy with simvastatin and fenofibrate significantly increased the large to small dense LDL ratio compared with simvastatin alone [54]. Third, fibrates were found to have their own anti-inflammatory actions, independent of their lipid-modifying activity. Fenofibrate therapy induced a decrease in the levels of circulating inflammatory markers and oxidative stress markers, and an increase in the levels of adiponectin, especially in patients with metabolic syndrome $[55,56]$. 


\section{CONCLUSIONS}

We presented a brief review of the evidence supporting the role of atherogenic dyslipidemia in cardiovascular risk prediction and the potential role of fibrates in cardiovascular risk reduction in patients with metabolic syndrome. The newly evolving evidence generally supports the value of fibrates in cardiovascular risk management and the need for well-designed CVOT focused on subjects with metabolic syndrome or atherogenic dyslipidemia. In conclusion, fibrate therapy would be considered as the optimal strategy for cardiovascular risk management in patients whose residual cardiovascular risk is expected to be moderate to high, even when treated with appropriate statin therapy, especially those with hypertriglyceridemia and/ or low HDL-C level.

\section{CONFLICTS OF INTEREST}

No potential conflict of interest relevant to this article was reported.

\section{ORCID}

Nam Hoon Kim https://orcid.org/0000-0002-9926-1344

Sin Gon Kim https://orcid.org/0000-0002-7430-3675

\section{ACKNOWLEDGMENTS}

None

\section{REFERENCES}

1. Kim HC. Epidemiology of dyslipidemia in Korea. J Korean Med Assoc 2016;59:352-7.

2. Rhee EJ, Kim HC, Kim JH, Lee EY, Kim BJ, Kim EM, Song Y, Lim JH, Kim HJ, Choi S, Moon MK, Na JO, Park KY, Oh MS, Han SY, Noh J, Yi KH, Lee SH, Hong SC, Jeong IK. 2018 Guidelines for the management of dyslipidemia. Korean J Intern Med 2019;34:723-71.

3. Goldstein JL, Brown MS. The LDL receptor. Arterioscler Thromb Vasc Biol 2009;29:431-8.

4. Pedersen TR. The success story of LDL cholesterol lowering. Circ Res 2016;118:721-31.

5. Stone NJ, Robinson JG, Lichtenstein AH, Bairey Merz CN, Blum CB, Eckel RH, Goldberg AC, Gordon D, Levy D, Lloyd-
Jones DM, McBride P, Schwartz JS, Shero ST, Smith SC Jr, Watson K, Wilson PW; American College of Cardiology/American Heart Association Task Force on Practice Guidelines. 2013 ACC/AHA guideline on the treatment of blood cholesterol to reduce atherosclerotic cardiovascular risk in adults: a report of the American College of Cardiology/American Heart Association Task Force on Practice Guidelines. J Am Coll Cardiol 2014;63:2889-934.

6. Fruchart JC, Sacks FM, Hermans MP, Assmann G, Brown WV, Ceska R, Chapman MJ, Dodson PM, Fioretto P, Ginsberg HN, Kadowaki T, Lablanche JM, Marx N, Plutzky J, Reiner Z, Rosenson RS, Staels B, Stock JK, Sy R, Wanner C, Zambon A, Zimmet P; Residual Risk Reduction Initiative (R3I). The residual risk reduction initiative: a call to action to reduce residual vascular risk in dyslipidaemic patient. Diab Vasc Dis Res 2008; 5:319-35.

7. Lloyd-Jones DM, Morris PB, Ballantyne CM, Birtcher KK, Daly DD Jr, DePalma SM, Minissian MB, Orringer CE, Smith SC Jr. 2017 Focused update of the 2016 ACC expert consensus decision pathway on the role of non-statin therapies for ldlcholesterol lowering in the management of atherosclerotic cardiovascular disease risk: a report of the American College of Cardiology task force on expert consensus decision pathways. J Am Coll Cardiol 2017;70:1785-822.

8. Grundy SM, Stone NJ, Bailey AL, Beam C, Birtcher KK, Blumenthal RS, Braun LT, de Ferranti S, Faiella-Tommasino J, Forman DE, Goldberg R, Heidenreich PA, Hlatky MA, Jones DW, Lloyd-Jones D, Lopez-Pajares N, Ndumele CE, Orringer CE, Peralta CA, Saseen JJ, Smith SC Jr, Sperling L, Virani SS, Yeboah J. 2018 AHA/ACC/AACVPR/AAPA/ABC/ACPM/ADA/AGS/ $\mathrm{APhA} / \mathrm{ASPC} / \mathrm{NLA} / \mathrm{PCNA}$ guideline on the management of blood cholesterol: executive summary: a report of the American College of Cardiology/American Heart Association task force on clinical practice guidelines. J Am Coll Cardiol 2019;73:3168209.

9. Mach F, Baigent C, Catapano AL, Koskinas KC, Casula M, Badimon L, Chapman MJ, De Backer GG, Delgado V, Ference BA, Graham IM, Halliday A, Landmesser U, Mihaylova B, Pedersen TR, Riccardi G, Richter DJ, Sabatine MS, Taskinen MR, Tokgozoglu L, Wiklund O; ESC Scientific Document Group. 2019 ESC/EAS guidelines for the management of dyslipidaemias: lipid modification to reduce cardiovascular risk. Eur Heart J 2020;41:111-88.

10. Chawla A, Repa JJ, Evans RM, Mangelsdorf DJ. Nuclear receptors and lipid physiology: opening the X-files. Science 2001; 
294:1866-70.

11. Berger J, Moller DE. The mechanisms of action of PPARs. Annu Rev Med 2002;53:409-35.

12. Heller F, Harvengt C. Effects of clofibrate, bezafibrate, fenofibrate and probucol on plasma lipolytic enzymes in normolipaemic subjects. Eur J Clin Pharmacol 1983;25:57-63.

13. Malmendier CL, Lontie JF, Delcroix C, Dubois DY, Magot T, De Roy L. Apolipoproteins C-II and C-III metabolism in hypertriglyceridemic patients. Effect of a drastic triglyceride reduction by combined diet restriction and fenofibrate administration. Atherosclerosis 1989;77:139-49.

14. Martin G, Schoonjans K, Lefebvre AM, Staels B, Auwerx J. Coordinate regulation of the expression of the fatty acid transport protein and acyl-CoA synthetase genes by PPARalpha and PPARgamma activators. J Biol Chem 1997;272:28210-7.

15. Schoonjans K, Watanabe M, Suzuki H, Mahfoudi A, Krey G, Wahli W, Grimaldi P, Staels B, Yamamoto T, Auwerx J. Induction of the acyl-coenzyme A synthetase gene by fibrates and fatty acids is mediated by a peroxisome proliferator response element in the C promoter. J Biol Chem 1995;270:19269-76.

16. Staels B, Auwerx J. Regulation of apo A-I gene expression by fibrates. Atherosclerosis 1998;137 Suppl:S19-23.

17. Marx N, Sukhova GK, Collins T, Libby P, Plutzky J. PPARalpha activators inhibit cytokine-induced vascular cell adhesion molecule-1 expression in human endothelial cells. Circulation 1999;99:3125-31.

18. Delerive P, Fruchart JC, Staels B. Peroxisome proliferator-activated receptors in inflammation control. J Endocrinol 2001; 169:453-9.

19. Sampson UK, Fazio S, Linton MF. Residual cardiovascular risk despite optimal LDL cholesterol reduction with statins: the evidence, etiology, and therapeutic challenges. Curr Atheroscler Rep 2012;14:1-10.

20. Boekholdt SM, Arsenault BJ, Mora S, Pedersen TR, LaRosa JC, Nestel PJ, Simes RJ, Durrington P, Hitman GA, Welch KM, DeMicco DA, Zwinderman AH, Clearfield MB, Downs JR, Tonkin AM, Colhoun HM, Gotto AM Jr, Ridker PM, Kastelein JJ. Association of LDL cholesterol, non-HDL cholesterol, and apolipoprotein B levels with risk of cardiovascular events among patients treated with statins: a meta-analysis. JAMA 2012;307:1302-9.

21. Miller M, Cannon CP, Murphy SA, Qin J, Ray KK, Braunwald E; PROVE IT-TIMI 22 Investigators. Impact of triglyceride levels beyond low-density lipoprotein cholesterol after acute coronary syndrome in the PROVE IT-TIMI 22 trial. J Am Coll
Cardiol 2008;51:724-30.

22. Barter P, Gotto AM, LaRosa JC, Maroni J, Szarek M, Grundy SM, Kastelein JJ, Bittner V, Fruchart JC; Treating to New Targets Investigators. HDL cholesterol, very low levels of LDL cholesterol, and cardiovascular events. N Engl J Med 2007;357: 1301-10.

23. Lawler PR, Akinkuolie AO, Chu AY, Shah SH, Kraus WE, Craig D, Padmanabhan L, Glynn RJ, Ridker PM, Chasman DI, Mora S. Atherogenic lipoprotein determinants of cardiovascular disease and residual risk among individuals with low lowdensity lipoprotein cholesterol. J Am Heart Assoc 2017;6.

24. Ray KK, Cannon CP, Cairns R, Morrow DA, Ridker PM, Braunwald E. Prognostic utility of apoB/AI, total cholesterol/ HDL, non-HDL cholesterol, or hs-CRP as predictors of clinical risk in patients receiving statin therapy after acute coronary syndromes: results from PROVE IT-TIMI 22. Arterioscler Thromb Vasc Biol 2009;29:424-30.

25. Tenenbaum A, Fisman EZ, Motro M, Adler Y. Atherogenic dyslipidemia in metabolic syndrome and type 2 diabetes: therapeutic options beyond statins. Cardiovasc Diabetol 2006;5:20.

26. Sirimarco G, Labreuche J, Bruckert E, Goldstein LB, Fox KM, Rothwell PM, Amarenco P; PERFORM and SPARCL Investigators and Committees. Atherogenic dyslipidemia and residual cardiovascular risk in statin-treated patients. Stroke 2014;45: 1429-36.

27. Jafri H, Alsheikh-Ali AA, Karas RH. Baseline and on-treatment high-density lipoprotein cholesterol and the risk of cancer in randomized controlled trials of lipid-altering therapy. J Am Coll Cardiol 2010;55:2846-54.

28. Kastelein JJ, Akdim F, Stroes ES, Zwinderman AH, Bots ML, Stalenhoef AF, Visseren FL, Sijbrands EJ, Trip MD, Stein EA, Gaudet D, Duivenvoorden R, Veltri EP, Marais AD, de Groot E; ENHANCE Investigators. Simvastatin with or without ezetimibe in familial hypercholesterolemia. N Engl J Med 2008;358: 1431-43.

29. ORIGIN Trial Investigators, Bosch J, Gerstein HC, Dagenais GR, Diaz R, Dyal L, Jung H, Maggiono AP, Probstfield J, Ramachandran A, Riddle MC, Ryden LE, Yusuf S. n-3 fatty acids and cardiovascular outcomes in patients with dysglycemia. $\mathrm{N}$ Engl J Med 2012;367:309-18.

30. AIM-HIGH Investigators, Boden WE, Probstfield JL, Anderson T, Chaitman BR, Desvignes-Nickens P, Koprowicz K, McBride R, Teo K, Weintraub W. Niacin in patients with low HDL cholesterol levels receiving intensive statin therapy. N Engl J Med 2011;365:2255-67. 
31. HPS2-THRIVE Collaborative Group, Landray MJ, Haynes R, Hopewell JC, Parish S, Aung T, Tomson J, Wallendszus K, Craig M, Jiang L, Collins R, Armitage J. Effects of extended-release niacin with laropiprant in high-risk patients. N Engl J Med 2014;371:203-12.

32. Schwartz GG, Olsson AG, Abt M, Ballantyne CM, Barter PJ, Brumm J, Chaitman BR, Holme IM, Kallend D, Leiter LA, Leitersdorf E, McMurray JJ, Mundl H, Nicholls SJ, Shah PK, Tardif JC, Wright RS; dal-OUTCOMES Investigators. Effects of dalcetrapib in patients with a recent acute coronary syndrome. N Engl J Med 2012;367:2089-99.

33. ACCORD Study Group, Ginsberg HN, Elam MB, Lovato LC, Crouse JR 3rd, Leiter LA, Linz P, Friedewald WT, Buse JB, Gerstein HC, Probstfield J, Grimm RH, Ismail-Beigi F, Bigger JT, Goff DC Jr, Cushman WC, Simons-Morton DG, Byington RP. Effects of combination lipid therapy in type 2 diabetes mellitus. N Engl J Med 2010;362:1563-74.

34. Ray KK, Corral P, Morales E, Nicholls SJ. Pharmacological lipid-modification therapies for prevention of ischaemic heart disease: current and future options. Lancet 2019;394:697-708.

35. Frick MH, Elo O, Haapa K, Heinonen OP, Heinsalmi P, Helo P, Huttunen JK, Kaitaniemi P, Koskinen P, Manninen V, Maenpaa H, Malkonen M, Manttari M, Norola S, Pasternack A, Pikkarainen J, Romo M, Sjoblom T, Nikkila EA. Helsinki Heart Study: primary-prevention trial with gemfibrozil in middle-aged men with dyslipidemia. Safety of treatment, changes in risk factors, and incidence of coronary heart disease. N Engl J Med 1987; 317:1237-45.

36. Rubins HB, Robins SJ, Collins D, Fye CL, Anderson JW, Elam MB, Faas FH, Linares E, Schaefer EJ, Schectman G, Wilt TJ, Wittes J. Gemfibrozil for the secondary prevention of coronary heart disease in men with low levels of high-density lipoprotein cholesterol. Veterans Affairs High-Density Lipoprotein Cholesterol Intervention Trial Study Group. N Engl J Med 1999; 341:410-8.

37. Bezafibrate Infarction Prevention (BIP) study. Secondary prevention by raising $\mathrm{HDL}$ cholesterol and reducing triglycerides in patients with coronary artery disease. Circulation 2000;102:21-7.

38. Meade T, Zuhrie R, Cook C, Cooper J. Bezafibrate in men with lower extremity arterial disease: randomised controlled trial. BMJ 2002;325:1139.

39. Keech A, Simes RJ, Barter P, Best J, Scott R, Taskinen MR, Forder P, Pillai A, Davis T, Glasziou P, Drury P, Kesaniemi YA, Sullivan D, Hunt D, Colman P, d'Emden M, Whiting M, Ehnholm C, Laakso M; FIELD study investigators. Effects of long-term fenofibrate therapy on cardiovascular events in 9795 people with type 2 diabetes mellitus (the FIELD study): randomised controlled trial. Lancet 2005;366:1849-61.

40. Elam MB, Ginsberg HN, Lovato LC, Corson M, Largay J, Leiter LA, Lopez C, O'Connor PJ, Sweeney ME, Weiss D, Friedewald WT, Buse JB, Gerstein HC, Probstfield J, Grimm R, IsmailBeigi F, Goff DC Jr, Fleg JL, Rosenberg Y, Byington RP; ACCORDION Study Investigators. Association of fenofibrate therapy with long-term cardiovascular risk in statin-treated patients with type 2 diabetes. JAMA Cardiol 2017;2:370-80.

41. Jun M, Foote C, Lv J, Neal B, Patel A, Nicholls SJ, Grobbee DE, Cass A, Chalmers J, Perkovic V. Effects of fibrates on cardiovascular outcomes: a systematic review and meta-analysis. Lancet 2010;375:1875-84.

42. Lee M, Saver JL, Towfighi A, Chow J, Ovbiagele B. Efficacy of fibrates for cardiovascular risk reduction in persons with atherogenic dyslipidemia: a meta-analysis. Atherosclerosis 2011;217: 492-8.

43. Bruckert E, Labreuche J, Deplanque D, Touboul PJ, Amarenco P. Fibrates effect on cardiovascular risk is greater in patients with high triglyceride levels or atherogenic dyslipidemia profile: a systematic review and meta-analysis. J Cardiovasc Pharmacol 2011;57:267-72.

44. American Diabetes Association. 9. Cardiovascular disease and risk management: standards of medical care in diabetes-2018. Diabetes Care 2018;41:S86-104.

45. Kim MK, Ko SH, Kim BY, Kang ES, Noh J, Kim SK, Park SO, Hur KY, Chon S, Moon MK, Kim NH, Kim SY, Rhee SY, Lee KW, Kim JH, Rhee EJ, Chun S, Yu SH, Kim DJ, Kwon HS, Park KS; Committee of Clinical Practice Guidelines, Korean Diabetes Association. 2019 Clinical practice guidelines for type 2 diabetes mellitus in Korea. Diabetes Metab J 2019;43:398-406.

46. Alperovitch A, Kurth T, Bertrand M, Ancelin ML, Helmer C, Debette S, Tzourio C. Primary prevention with lipid lowering drugs and long term risk of vascular events in older people: population based cohort study. BMJ 2015;350:h2335.

47. Kim NH, Han KH, Choi J, Lee J, Kim SG. Use of fenofibrate on cardiovascular outcomes in statin users with metabolic syndrome: propensity matched cohort study. BMJ 2019;366:15125.

48. Suissa S. Lower risk of death with SGLT2 inhibitors in observational studies: real or bias? Diabetes Care 2018;41:6-10.

49. Pradhan AD, Paynter NP, Everett BM, Glynn RJ, Amarenco P, Elam M, Ginsberg H, Hiatt WR, Ishibashi S, Koenig W, Nordestgaard BG, Fruchart JC, Libby P, Ridker PM. Rationale and design of the pemafibrate to reduce cardiovascular outcomes 
by reducing triglycerides in patients with diabetes (PROMINENT) study. Am Heart J 2018;206:80-93.

50. Mellies MJ, Stein EA, Khoury P, Lamkin G, Glueck CJ. Effects of fenofibrate on lipids, lipoproteins, and apolipoproteins in 33 subjects with primary hypercholesterolemia. Atherosclerosis 1987;63:57-64.

51. Rizos E, Bairaktari E, Ganotakis E, Tsimihodimos V, Mikhailidis DP, Elisaf M. Effect of ciprofibrate on lipoproteins, fibrinogen, renal function, and hepatic enzymes. J Cardiovasc Pharmacol Ther 2002;7:219-26.

52. Miller M, Bachorik PS, McCrindle BW, Kwiterovich PO Jr. Effect of gemfibrozil in men with primary isolated low high-density lipoprotein cholesterol: a randomized, double-blind, placebo-controlled, crossover study. Am J Med 1993;94:7-12.

53. Watts GF, Barrett PH, Ji J, Serone AP, Chan DC, Croft KD, Loehrer F, Johnson AG. Differential regulation of lipoprotein kinetics by atorvastatin and fenofibrate in subjects with the metabolic syndrome. Diabetes 2003;52:803-11.

54. Vega GL, Ma PT, Cater NB, Filipchuk N, Meguro S, GarciaGarcia AB, Grundy SM. Effects of adding fenofibrate $(200 \mathrm{mg} /$ day) to simvastatin $(10 \mathrm{mg} /$ day $)$ in patients with combined hyperlipidemia and metabolic syndrome. Am J Cardiol 2003;91: 956-60.

55. Belfort R, Berria R, Cornell J, Cusi K. Fenofibrate reduces systemic inflammation markers independent of its effects on lipid and glucose metabolism in patients with the metabolic syndrome. J Clin Endocrinol Metab 2010;95:829-36.

56. Krysiak R, Gdula-Dymek A, Bachowski R, Okopien B. Pleiotropic effects of atorvastatin and fenofibrate in metabolic syndrome and different types of pre-diabetes. Diabetes Care 2010; 33:2266-70. 